\title{
Botryoid Odontogenic Cyst with Extensive Clear Cells
}

\author{
Benay Yildirim and Emre Baris* \\ Department of Oral Pathology, Turkey \\ *Corresponding author: Emre Baris, Department of Oral Pathology, Turkey
}

ARTICLE INFO

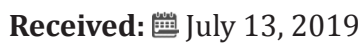

Published: 㓞 July 19, 2019

Citation: Benay Yildirim, Emre Baris. Botryoid Odontogenic Cyst with Extensive Clear Cells. Biomed J Sci \& Tech Res 19(5)-2019. BJSTR. MS.ID.003360.

\begin{abstract}
Botryoid odontogenic cysts (BOC) is an unusual multi cystic variant of the lateral periodontal cyst. We report a case of BOC in a 29-year-old male patient. Radiographic examination revealed a multi locular radiolucency from the mandibular right premolar area, involving almost the whole height of the mandible. Histologically the cystic lesion was lined by a thin 2-4 layered non- keratinised epithelium without rete ridges, with few plaque like thickenings and occasional mural bulges. The most characteristic feature was the extensive clear cells within the cyst lining, in epithelial plaques and among epithelial rests scattered within the fibrous connective-tissue wall
\end{abstract}

Keywords: Odontogenic Cyst; Botryoid Odontogenic Cyst; Clear Cell Variant; Lateral Periodontal Cyst

\section{Introduction}

Botryoid odontogenic cysts (BOC) is a multicystic variant of the lateral periodontal cyst, a developmental cyst believed to arise from remnants of the dental lamina. Similar to the conventional lateral periodontal cyst, the BOC exhibits a predilection for the mandibular canine and first premolar region. Swelling has been reported in more than one-half of cases, although many patients are asymptomatic. Pain, drainage and paresthesia rarely have been reported [1]. The term "botryoid" means "grapelike," and these lesions may appear multi locular radiographically, grossly and/or microscopically. Similar to the lateral periodontal cyst, the microscopic features of the BOC include a thin epithelial cyst lining composed of flattened squamous or cuboidal cells with focal plaque like thickenings. Rarely clear cells may be seen within the cyst lining or among epithelial rests scattered within the fibrous connective-tissue wall $[2,3]$.

\section{Case Report}

A 29 year-old male was treated for a residual cyst at the site of the mandibular right premolar area, involving almost the whole height of the right mandible. The teeth were extracted one year ago. The cyst was $2.5 \times 0.5 \times 0.5 \mathrm{~cm}$ in diameter. Excisional biopsy material revealed a multicystic lesion. Microscopically the thin epithelial cyst lining was composed of flattened squamous and cuboidal cells with focal plaque like thickenings (Figure 1).
Extensive clear cells were observed within the cyst lining, epithelial plaques and among epithelial rests, that were scattered within the fibrous connective-tissue wall. The fibrous cyst wall was free of inflammation (Figure 2).

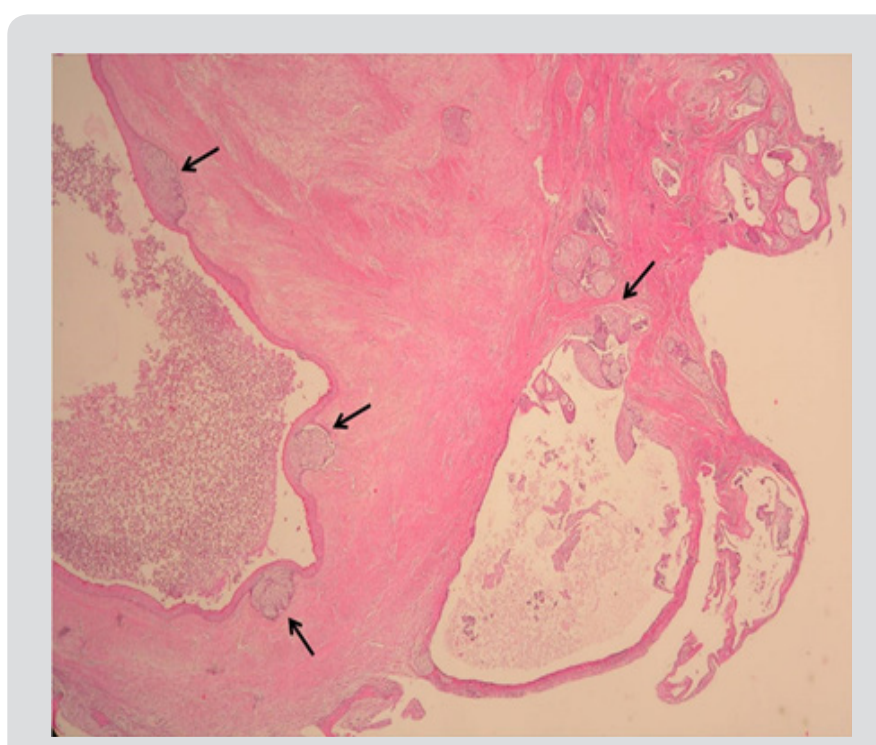

Figure 1: The multicystic lesion was lined by thin epithelium that is composed of flattened squamous and cuboidal cells with focal plaque like thickening. (Hematoxylin \& Eosin $x 40$ ). 


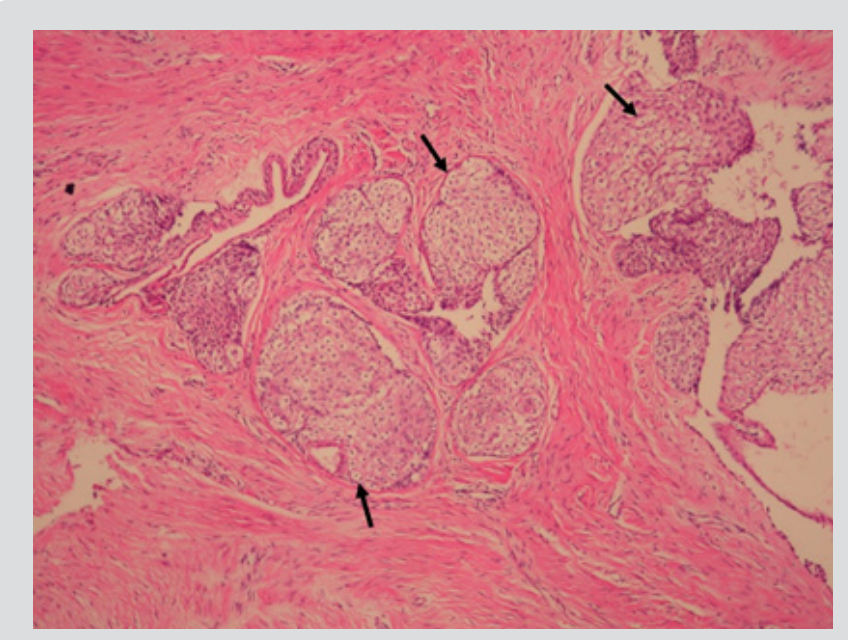

Figure 2: Extensive clear cells were seen within the cyst lining, epithelial plaques and among epithelial rests, that were scattered within the fibrous connective-tissue wall (Hematoxylin \& Eosin x200).

\section{Discussion}

Since its original description, BOC has been widely regarded as a variant of the lateral periodontal cyst $[2,4,5]$. Microscopically, the lesion is quite similar to the lateral periodontal cyst but exhibits some differences. The lesion is multicystic with thin fibrous connective tissue septa. The cyst cavities are of varying size. The cysts are generally lined by thin non-keratinised stratified squamous epithelium. In many of the cysts there are foci of plaque like epithelial thickenings [5]. Weathers and Waldron suggested that these plaques may possibly be the source of new cyst locules. Clear cells are unusual both in the lining epithelium and in the plaques [5]. The present case showed extensive clear cells which is unusual for BOCs. Radiographically, most BOC are monocytes; but occasional polycystic (multilocular) cases have been encountered The most frequent location of BOC is the mandibular premolar area, followed by the anterior region of the maxilla [4].

Radiographically, there are similarities between BOC and some odontogenic tumors such as ameloblastoma, odontogenic myxoma, adenomatoid odontogenic tumor and various others in terms of appearance. Preoperative differential diagnosis can be carried out by means of incisional biopsy 4,5 . In the present case the histopathological features were consistent with BOC. The cyst cavities separated with fibrous septa were lined by flattened squamous and cuboidal cells with focal plaque like thickenings. BOC rarely may show clear cells, in our case extensive clear cells were observed within the cyst lining, plaques and among epithelial rests scattered within the fibrous connective-tissue wall. Because lateral periodontal cysts usually show clear cells, most investigators have concluded that they arise from dental lamina remnants, which sometimes present clear cells, unlike reduced enamel epithelia, rests of Malassez [6]. Bascones [7] in the histopathological study of a periapical lesion attached to a superior canine in a 54-yearold male, has yielded a singular finding that may shed light on the genesis of some odontogenic lesions.

The lesion showed histopathological indisputable presence of several apparently inactive epithelial nests composed of clear cells. Their morphology and location in the periodontal ligament led them to identify them as epithelial rests of Malassez. Their clear appearance was a surprising finding, not previously reported in the literature. This finding indicates that the rests of Malassez cannot be ruled out as the origin of lateral periodontal cyst and also its variant BOC.

BOC is known to be a recurrent odontogenic cyst. The recurrence rate may range between 15 and $20 \%$. The proliferation rate of the epithelial lining, size and multilocular patterns has to be determined to estimate the possibility of recurrence $[4,8]$. High recurrence rate detected in the studies, suggests the need of a more aggressive treatment than usually applied and an appropriate follow up period.

\section{References}

1. Angela C Chi, Brad W Neville, Brent J Klinger (2007) A multilocular radiolucency. J Am Dent Assoc 138: 1102-1103.

2. BW Neville, DD Damm, CM Allen, JE B (2009) Oral and Maxillofacial Parhology ( $3^{\text {rd }}$ edn.). Philadelphia: Saunders pp. 692-695.

3. Rui Amaral Mendes, Isaac van der Waal (2006) An unusual clinicoradiographic presentation of a lateral periodontal cyst - report of two cases. Med Oral Patol Oral Cir Bucal 11(2): E185-187.

4. O Ucok, Z Yaman, O Gunhan, C Ucok, N Doğan, et al. (2005) Botryoid odontogenic cyst: report of a case with extensive epithelial proliferation. Int J Oral Maxillofac Surg 34(6): 693-695.

5. M Shear, PM Speight (2007) Cysts of Oral and Maxillofacial Regions ( $4^{\text {th }}$ edn). Blackwell pp. 91-93.

6. Wysocki GP, Brannon RB, Gardner DG, Sapp JP (1980) Histogenesis of the lateral periodontal cyst and the gingival cyst of the adult. Oral Surg Oral Med Oral Pathol 50(4): 327-334.

7. Bascones, F Llanes (2005) Clear cells in epithelial rests of Malassez. Oral Oncology 41(1): 99-100.

8. Pedro Méndez, Luis Junquera, Lorena Gallego, Jaime Baladrón (2007) Botryoid odontogenic cyst: clinical and pathological analysis in relation to recurrence. Med Oral Patol Oral Cir Bucal 12(8): E594-598. 


\section{ISSN: 2574-1241}

DOI: 10.26717/BJSTR.2019.19.003360

Emre Baris. Biomed J Sci \& Tech Res

(c) (i) This work is licensed under Creative

Submission Link: https://biomedres.us/submit-manuscript.php

$\begin{array}{ll}\text { BIOMEDICAL } & \text { Assets of Publishing with us } \\ \text { RESEARCHES } & \text { - Global archiving of articles } \\ \text { - Immediate, unrestricted online access } \\ \text { - Rigorous Peer Review Process }\end{array}$

